Ryuji Yajima, MD, PhD

Kota Utsumi, MD

Tomohiko Ishihara, MD, $\mathrm{PhD}$

Masato Kanazawa, MD, $\mathrm{PhD}$

Kouichirou Okamoto, $\mathrm{MD}, \mathrm{PhD}$

Izumi Kawachi, MD, $\mathrm{PhD}$

Masatoyo Nishizawa, $\mathrm{MD}, \mathrm{PhD}$

Neurol Neuroimmunol Neuroinflamm 2015;2:e108; doi: 10.1212 NXI.0000000000000108

\section{VARICELLA-ZOSTER VIRUS ENCEPHALITIS LOCALIZED TO THE BILATERAL MEDIAL TEMPORAL LOBES \\ OPEN}

Case report. An immunocompetent 66-year-old man was admitted to a local hospital with fever and severe amnesia without a rash. T2-weighted MRI revealed symmetric hyperintense lesions in the bilateral medial temporal lobes. Magnetic resonance angiography showed no abnormalities. CSF analysis revealed 14 leukocytes $/ \mathrm{mm}^{3}$ and protein and glucose concentrations of $34 \mathrm{mg} / \mathrm{dL}$ and $79 \mathrm{mg} / \mathrm{dL}$, respectively. He was administered IV acyclovir (1,500 mg/day) for suspected herpes simplex virus (HSV) encephalitis. He did not recover and was transferred to our university hospital on day 11 . On admission, his temperature was $37^{\circ} \mathrm{C}$ and he had no rash. A neurologic examination showed no focal signs except severe anterograde amnesia. He remembered nothing of the past few days. His MiniMental State Examination score was 21/30. His delayed recall was most impaired. Laboratory results showed increased antinuclear antibody (ANA, 104.4 index) and anti-SSA/Ro antibody (108.4 index). All antibodies to known neuronal antigens were negative, including NMDA receptor, leucine-rich gliomainactivated 1, and glutamic acid decarboxylase. Antivaricella-zoster virus (VZV) IgG (40.9 enzyme immunoassay [EIA] units $/ \mathrm{mL}$ ) was elevated, but IgM (0.30 EIA units $/ \mathrm{mL}$ ) was not. CSF analysis revealed pleocytosis; normal glucose, protein, and myelin basic protein levels; and the absence of oligoclonal bands. The IgG index was 0.71. The antibody index to VZV (the ratio of CSF/serum-specific IgG antibodies to VZV compared with $\mathrm{CSF} /$ serum total $\mathrm{IgG}$ ) was elevated at 2.8 (normal <2.0). PCR for CSF was positive for VZV $(13,000$ copies $/ \mathrm{mL})$ and negative for HSV, human herpesvirus 6, Epstein-Barr virus, and cytomegalovirus. Diffusion-weighted (figure, A), T2-weighted (figure, B), and fluid-attenuated inversion recovery (figure, $C$ ) images from a brain MRI showed lesions more clearly than the images from the previous hospital. The lesions were not enhanced on gadolinium-enhanced T1-weighted images (figure, D). Contrast-enhanced CT of the chest, abdomen, and pelvis was normal.

Based on PCR for VZV DNA in CSF and the elevated VZV antibody index reflecting intrathecal production of anti-VZV antibodies, ${ }^{1,2}$ the patient was diagnosed with limbic encephalitis (LE) caused by VZV without a rash. He was treated with IV acyclovir (1,500 $\mathrm{mg} /$ day for 19 days) and methylprednisolone pulse therapy followed by oral prednisolone $(50 \mathrm{mg} /$ day for 21 days and thereafter gradually decreased). A follow-up MRI showed improvements in abnormal signal intensity and atrophy in the same areas. PCR for VZV DNA became negative, and the VZV antibody index normalized. His amnesia slightly improved.

Discussion. Reactivation of VZV is associated with various CNS complications, particularly in immunocompromised patients. ${ }^{3}$ Among these, VZV encephalitis is important, as its prognosis is poorer than VZV meningitis. $^{2}$ In contrast to more common lesions such as gray-white matter junction lesions, ${ }^{2}$ localized focal symmetric medial temporal lesions are extremely rare. To our knowledge, only one such case has been reported, in an immunocompromised patient who had undergone prolonged immunosuppressive therapy. ${ }^{4} \mathrm{He}$ showed limbic lesions extending to the basal ganglia and died. In comparison, our patient had the following features: (1) the absence of major risk factors for VZV encephalitis, (2) localized bilateral medial temporal lobe lesions, and (3) survival with mild cognitive recovery. LE due to HSV infection or paraneoplastic neurologic syndromes could be excluded based on the results of various examinations. We believe the ANA and antiSSA/Ro antibody elevation reflects an autoimmune mechanism for this condition; however, the patient did not show any findings suggesting a connective tissue disorder such as systemic lupus erythematosus or Sjögren syndrome. Although acute disseminated encephalomyelitis associated with VZV infection is common, it is unlikely because the lesions are symmetric and confined to the bilateral medial temporal lobes. With the exception of old age, the patient had no risk factors for VZV encephalitis.

Three mechanisms have been proposed for the pathophysiology of VZV encephalitis: demyelinating disease, vasculopathy, and acute infectious encephalitis of undetermined pathophysiology. ${ }^{5}$ However, the most likely pathophysiology in this case is an autoimmune mechanism, based on the symmetric lesions and changes in MRI signal intensity and anatomic structure with time. HSV occurs primarily in the limbic system. 

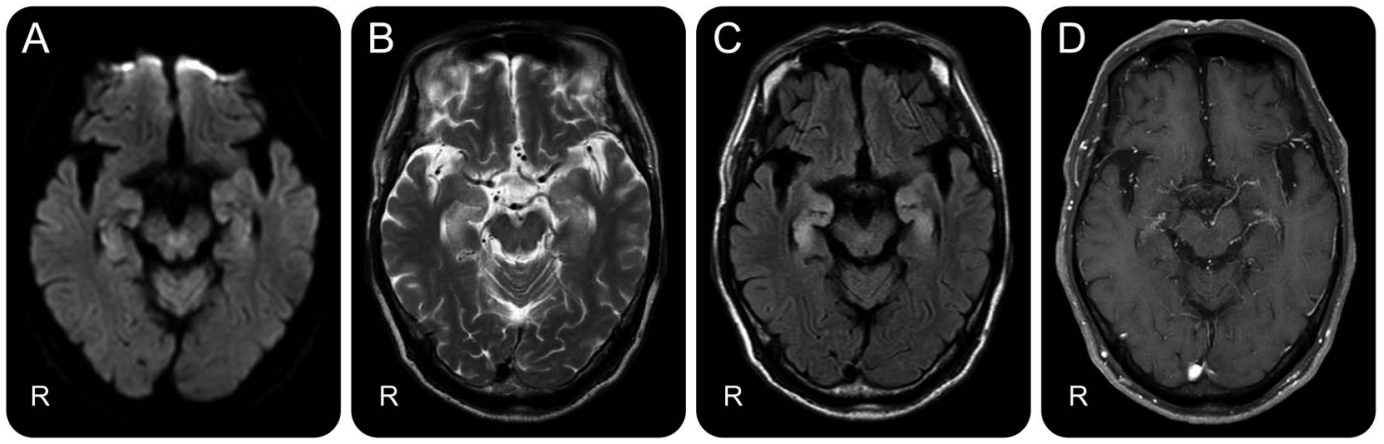

The diffusion-weighted image (A), T2-weighted image (B), and fluid-attenuated inversion recovery image (C) revealed areas of hyperintensity with mild edema in the bilateral medial area of the temporal lobes. The gadolinium-enhanced T1-weighted image (D) showed no apparent enhancement.

HSV infection can be a trigger of autoimmunemediated anti-NMDA receptor encephalitis. ${ }^{6}$ Whether this mechanism is specific to HSV is unclear. VZV reactivation might also cause autoimmune encephalitis through an unidentified antibody because VZV is highly neurotrophic like HSV.

Although the administration of acyclovir is recommended, ${ }^{1}$ combined acyclovir/steroid treatment might be effective, as this treatment would prevent deterioration in immunocompetent patients with an autoimmune mechanism. ${ }^{7}$

From the Departments of Neurology (R.Y., K.U., T.I., M.K., I.K., M.N.) and Neurosurgery (K.O.), Brain Research Institute, Niigata University, Niigata, Japan.

Author contributions: Dr. Yajima was involved in patient care, wrote the draft of the manuscript, and prepared the figure. Dr. Utsumi coordinated patient care. Dr. Ishihara was involved in patient care and contributed to revising the manuscript. Dr. Kanazawa was involved in patient care and contributed to revising the manuscript. Dr. Okamoto contributed to the interpretation of the MRI results. Dr. Kawachi contributed to revising the manuscript. Dr. Nishizawa supervised, edited and revised the manuscript, and was responsible for the final version.

Acknowledgment: The authors thank Professor Josep Dalmau (ICREA-IDIBAPS-Hospital Clinic, University of Barcelona, Spain) for the measurement of antineuronal antibodies.

Study funding: No targeted funding reported.

Disclosure: R. Yajima, K. Utsumi, T. Ishihara, M. Kanazawa, and $K$. Okamoto report no disclosures. I. Kawachi received travel funding and speaker honoraria from Novartis Pharma, Biogen Idec, Takeda Pharmaceutical Company Limited, and Bayer Schering Pharma and received research support from JSPS KAKENHI. M. Nishizawa received research support from Takeda, Eisai, Kissei, DainihonSumitomo, Ono, Tanabe-Mitsubishi, MSD, Ministry of Health, Labor and Welfare, Japan, and Japan Society for Promotion of Science.
Go to Neurology.org/nn for full disclosure forms. The Article Processing Charge was paid by the authors.

This is an open-access article distributed under the terms of the Creative Commons Attribution-Non Commercial-No Derivatives License 4.0 (CCBY-NC-ND), where it is permissible to download and share the work provided it is properly cited. The work cannot be changed in any way or used commercially.

Received March 15, 2015. Accepted in final form March 23, 2015.

Correspondence to Dr. Nishizawa:nishi@bri.niigata-u.ac.jp

1. Tunkel AR, Glaser CA, Bloch KC, et al; Infectious Diseases Society of America. The management of encephalitis: clinical practice guidelines by the Infectious Diseases Society of America. Clin Infect Dis 2008;47:303-327.

2. Nagel MA, Cohrs RJ, Mahalingam R, et al. The varicella zoster virus vasculopathies: clinical, CSF, imaging, and virologic features. Neurology 2008;70:853-860.

3. Steiner I, Kennedy PG, Pachner AR. The neurotropic herpes viruses: herpes simplex and varicella-zoster. Lancet Neurology 2007;6:1015-1028.

4. Tattevin P, Schortgen F, de Broucker T, Dautheville S, Wolff M. Varicella-zoster virus limbic encephalitis in an immunocompromised patient. Scand J Infect Dis 2001;33: 786-788.

5. De Broucker T, Mailles A, Chabrier S, Morand P, Stahl JP; steering committee and investigators group. Acute varicella zoster encephalitis without evidence of primary vasculopathy in a caseseries of 20 patients. Clin Microbiol Infect 2012;18:808-819.

6. Desena A, Graves D, Warnack W, Greenberg BM. Herpes simplex encephalitis as a potential cause of anti-N-methylD-aspartate receptor antibody encephalitis: report of 2 cases. JAMA Neurol 2014;71:344-346.

7. Steiner I, Budka H, Chaudhuri A, et al. Viral encephalitis: a review of diagnostic methods and guidelines for management. Eur J Neurol 2005;12:331-343. 


\section{Neurology \\ Neuroimmunology \& Neuroinflammation}

\section{Varicella-zoster virus encephalitis localized to the bilateral medial temporal lobes Ryuji Yajima, Kota Utsumi, Tomohiko Ishihara, et al. \\ Neurol Neuroimmunol Neuroinflamm 2015;2; \\ DOI 10.1212/NXI.0000000000000108}

This information is current as of May 7, 2015

\section{Updated Information \& Services}

References

Subspecialty Collections

Permissions \& Licensing

Reprints including high resolution figures, can be found at:

http://nn.neurology.org/content/2/4/e108.full.html

This article cites 7 articles, 0 of which you can access for free at: http://nn.neurology.org/content/2/4/e108.full.html\#\#ref-list-1

This article, along with others on similar topics, appears in the following collection(s):

Autoimmune diseases

http://nn.neurology.org//cgi/collection/autoimmune_diseases

Encephalitis

http://nn.neurology.org//cgi/collection/encephalitis

Memory

http://nn.neurology.org//cgi/collection/memory

MRI

http://nn.neurology.org//cgi/collection/mri

Viral infections

http://nn.neurology.org//cgi/collection/viral_infections

Information about reproducing this article in parts (figures,tables) or in its entirety can be found online at:

http://nn.neurology.org/misc/about.xhtml\#permissions

Information about ordering reprints can be found online:

http://nn.neurology.org/misc/addir.xhtml\#reprintsus

Neurol Neuroimmunol Neuroinflamm is an official journal of the American Academy of Neurology.

Published since April 2014, it is an open-access, online-only, continuous publication journal. Copyright $\odot$ 2015 American Academy of Neurology. All rights reserved. Online ISSN: 2332-7812.

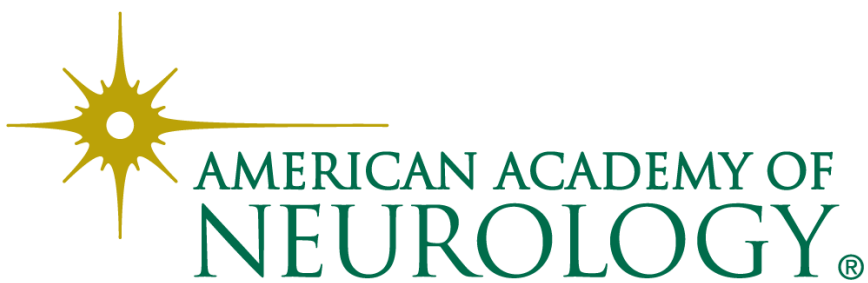

